A N N A LES

UNIVERSITATIS MARIAE CURIE-SKŁODOWSKA LUBLIN - POLONIA

VOL. LXIII, 1 SECTIO G 2016

Uniwersytet Marii Curie-Skłodowskiej w Lublinie pawel.lesinski@interia.pl

PAWEŁ LESIŃSKI

\title{
Myśl realistyczna a bezpieczeństwo Polski w kontekście współczesnych relacji z Federacją Rosyjską i Stanami Zjednoczonymi
}

The Realist Thought and the Security of Poland in the Context of Contemporary Polish-Us and Polish-Russian Foreign Relations

\section{WPROWADZENIE}

Niniejszy artykuł podejmuje próbę omówienia oraz wskazania adekwatności i przydatności założeń doktryny realizmu stosunków międzynarodowych w odniesieniu do problemu zapewnienia bezpieczeństwa Rzeczypospolitej Polskiej, postrzeganego przez pryzmat relacji z Federacją Rosyjską i Stanami Zjednoczonymi. Celem opracowania nie jest formułowanie ostatecznych koncepcji czy absolutnych prawd, lecz udowodnienie, iż w obecnych warunkach geopolitycznych to właśnie realizm może być odpowiedzią na pytanie, które nurtowało pokolenia Polaków od bez mała 200 lat, mianowicie jak zapewnić naszemu krajowi bezpieczeństwo będące wartością wyjściową dla dalszego jego rozwoju.

Artykuł składa się z trzech części. Pierwsza z nich jest próbą omówienia źródeł doktryny realizmu politycznego ${ }^{1}$. W drugiej zostały przedstawione założenia myśli realistów dwudziestowiecznych, przydatne dla polityki bezpieczeń-

1 Dominująca w dwudziestowiecznych stosunkach międzynarodowych doktryna, mówiąca o głównej roli siły i interesów partykularnych w relacjach między państwami mającymi podporządkowywać sobie podmioty słabsze, często wbrew prawu międzynarodowemu i zbiorowym systemom bezpieczeństwa. Za: A. Heywood, Klucz do politologii, najważniejsze ideologie, systemy, postaci, Warszawa 2008, s. 161-162. 
stwa państwa polskiego. Część trzecia jest analizą stosunków Polski z Federacją Rosyjską i Stanami Zjednoczonymi zgodnie z przedstawionymi w poprzednich częściach założeniami myśli realistycznej.

\section{ŹRÓDŁA MYŚLI}

W mojej ocenie rzeczą niezbędną dla właściwego poznania doktryny realistycznej i próby przeniesienia jej na grunt polskiego bezpieczeństwa jest poznanie jej podstaw oraz rozwoju na przestrzeni lat. Pozwoli to na odpowiednie umiejscowienie myśli w czasie, a także udowodni, że pewne mechanizmy stosunków międzynarodowych nie ulegają zmianom, mimo że były opisywane już w starożytności. Jacek Czaputowicz znajduje źródła doktryny realistycznej w twórczości Tukidydesa ${ }^{2}$, nazywanego też przedstawicielem realizmu klasycznego ${ }^{3}$. Niezwykle ważne dla dalszych rozważań na temat bezpieczeństwa Rzeczypospolitej jest przytoczenie poglądu tego greckiego myśliciela na sytuację występowania nierówności między państwami. Był on przekonany o tym, iż stan, w którym istnieją między poszczególnymi krajami i narodami duże różnice (przede wszystkim w ich potencjale obronnym i politycznym), jest rzeczą nieuchronną i niejako „naturalną". Nierówność ta powoduje, że wszystkie państwa muszą się do niej dostosowywać i postępować według jej reguł. W przeciwnym razie (gdy prowadzą politykę oderwaną od powyższych realiów) grozi im osłabienie, a nawet upadek ${ }^{4}$.

Kolejnym poglądem cechującym Tukidydesa było przekonanie o dążeniu każdego państwa do maksymalizacji swej siły na arenie międzynarodowej. Działanie takie było według niego ,wymuszane” przez strukturę systemu relacji między państwami ${ }^{5}$, gdzie dominowały stosunki ukierunkowane na zdobycie przewagi nad innymi ${ }^{6}$. Ponadto grecki historyk był przekonany o nadrzędnej wartości siły państwa (a nie np. prawa międzynarodowego) w stosunkach międzynarodowych. Siła ta jednak nie była rozumiana przez niego jako wartość absolutna, lecz mierzona w stosunku do sił innych krajów, z którymi aktualnie prowadzi się spór czy wojnę ${ }^{7}$.

2 Piotr Kimla początków myśli realistycznej dopatruje się jednak w twórczości pierwszej generacji sofistów, a ściślej u Protagorasa z Abdery, uznając go za prekursora realizmu politycznego. Zob. P. Kimla, U źródeł realizmu politycznego. Sofista pierwszej generacji-Protagoras z Abdery, „Politeja” 2004, nr 1.

3 J. Czaputowicz, Teorie stosunków międzynarodowych: krytyka i systematyzacja, Warszawa 2008, s. 72-73. W Wojnie peloponeskiej Tukidydes opisuje trwający w latach 431-404 p.n.e. konflikt między starożytnymi Atenami a Spartą.

4 R. Jackson, G. Sorensen, Wprowadzenie do stosunków międzynarodowych, Kraków 2012, s. 64.

5 Odniesienie się do struktury systemu międzynarodowego będzie również charakterystyczne dla opisanej w dalszej części artykułu myśli Kennetha Waltza.

6 P. Kimla, Historycy-politycy jako źródło realizmu politycznego, Kraków 2009, s. 53.

7 J. Czaputowicz, Teorie stosunków..., s. 60-61. 
Do prekursorów myśli realistycznej należy zaliczyć też Włocha - Niccolo Machiavellego. Realizm w jego wydaniu (nazywany również realizmem fundamentalnym $)^{8}$ zakłada, że polityka zagraniczna - a szczególnie zapewnienie bezpieczeństwa państwu - powinna się opierać na sile i przebiegłości władcy. Państwo silne to przede wszystkim państwo niebędące łatwym łupem dla potencjalnych wrogów, będące odpowiednio potężne, aby zapewnić sobie przetrwanie, ale i realizację własnych interesów ${ }^{9}$.

Jak wspomniałem, oprócz siły, do realizacji interesów państwa i zapewnienia mu bezpieczeństwa jako wartości nadrzędnej w doktrynie Machiavellego potrzebna jest również przebiegłość władcy (dziś powiedzielibyśmy raczej: klasy rządzącej). Owa przebiegłość powinna się objawiać w zdolności do umiejętnego odczytywania i zapobiegania niebezpieczeństwom grożącym przetrwaniu organizmu państwowego ${ }^{10}$. Aby móc zrealizować interes nadrzędny, władcy powinni według Machiavellego kierować się tylko kryterium skuteczności w realizacji racji stanu. Efektem takiego rozumowania jest przekonanie o możliwości dokonywania przez władców zdrad lub oszustw w imię spełnienia interesu państwa ${ }^{11}$.

Źródeł myśli realistycznej można się dopatrywać także w twórczości Jana Jakuba Rousseau ${ }^{12}$. Prezentował on jednak pogląd nieco odmienny od Machiavellego, uważał bowiem, że pokój i bezpieczeństwo między państwami mogą być zapewnione przez równowagę sił oraz wzrost współzależności i współpracy gospodarczej albo przez system bezpieczeństwa zbiorowego gwarantowany przez powołaną w tym celu organizację międzynarodową. Na pierwszy rzut oka Rousseau prezentował raczej podejście idealistyczne do stosunków międzynarodowych. Pozycjonować go wśród prekursorów myśli realistycznej pozwala jednak fakt, iż był świadom ułomności systemu bezpieczeństwa zbiorowego, gdyż (podobnie jak Machiavelli) zauważał, że monarchowie (czy też kraje) kierują się raczej interesem własnym, a nie zbiorowym. Państwa według Rousseau będą porzucać obowiązki kolektywne na rzecz zysków indywidualnych, nawet gdy są one znacznie mniejsze ${ }^{13}$.

8 Zob. ibidem, s. 63-64.

9 P. Kimla, Historycy-politycy..., s. 138.

10 J. Malarczyk, Uźródet włoskiego realizmu politycznego: Machiavelli i Guicciardini, Lublin 1963, s. 130 .

${ }^{11}$ Zasadę tę dobrze ilustruje cytat z Księcia autorstwa Machiavellego: „Otóż mądry pan nie może ani nie powinien dotrzymywać wiary, jeżeli takie dotrzymywanie przynosi mu szkodę i gdy zniknęły przyczyny, które spowodowały jego przyrzeczenie. Zapewne gdyby wszyscy ludzie byli dobrzy, ten przepis nie byłby dobry, lecz ponieważ są oni nikczemni i nie dotrzymywaliby tobie wiary, więc ty także nie jesteś obowiązany im jej dotrzymywać. A nigdy nie braknie księciu przyczyn prawnych, by upiększyć wiarołomstwo". Zob. N. Machiavelli, Książę, Warszawa 1993, s. 68.

12 J. Czaputowicz, Teorie stosunków..., s. 64-68.

${ }_{13}$ Mówiąc o Rousseau w kontekście bezpieczeństwa Polski, należy wspomnieć o jego koncepcji „nieprowokacyjnej obrony”. Według tej koncepcji państwa otoczone przez silnych sąsiadów 
Ważna dla zrozumienia podstaw doktryny realizmu jest też myśl Thomasa Hobbesa, którego charakteryzowała koncepcja oparcia stosunków międzynarodowych na równowadze sił. Mechanizm owej równowagi zakłada, iż w obliczu nieistnienia rodzaju światowego imperium - regulującego stosunki między państwami i zarządzającego sferą bezpieczeństwa - dochodzi do wytworzenia się systemu międzynarodowej anarchii, rodzącego współzależności między bezpieczeństwem państw. Dla Hobbesa, podobnie jak dla Machiavellego, przetrwanie i bezpieczeństwo państwa są celami minimalnymi, a maksymalnym celem jest zwiększenie stanu posiadania ${ }^{14}$. Państwa, aby zapewniać sobie bezpieczeństwo, mogą co prawda zawierać sojusze czy tworzyć prawo międzynarodowe, lecz jako organizmy z reguły egoistyczne (co ważne dla bezpieczeństwa Polski) będą przestrzegać łączącego je prawa międzynarodowego tylko wówczas, gdy będzie leżało to $\mathrm{w}$ ich interesie ${ }^{15}$. Fakt, że w świecie nie ma tak naprawdę instytucji mogącej egzekwować przestrzeganie porządku i praw międzynarodowych, sprawia, że według Hobbesa w dziedzinie bezpieczeństwa państwa zdane są tylko na siebie ${ }^{16}$.

\section{DWUDZIESTOWIECZNY REALIZM I NEOREALIZM}

Znając podstawowe założenia i prekursorów myśli realistycznej, należy się odnieść do jej dwudziestowiecznych twórców, z których za pierwszego uważa się Edwarda H. Carra, zaliczanego przez Scotta Burchilla do tzw. wczesnych realistów ${ }^{17}$. W 1939 r. Carr wydał pracę zatytułowaną The Twenty Years' Crisis, będącą przede wszystkim krytyką szeroko rozpowszechnionego w dwudziestoleciu międzywojennym idealizmu stosunków międzynarodowych, który zaowocował powstaniem Ligi Narodów i prawie bezgraniczną wiarą w wartość prawa międzynarodowego ${ }^{18}$.

powinny, po pierwsze, posiadać sprawiedliwą władzę centralną, a także wzmacniać patriotyzm i więzi narodowe. Aby jednak nie być postrzeganym przez sąsiadów jako zagrożenie, powinny posiadać tylko lekko uzbrojone oddziały milicji zdolne do utrzymania porządku, a nie regularną armię. Nie czyniłoby to z takiego państwa łatwej ofiary, gdyż oddziały takie mogłyby ewentualnego najeźdźcę nękać wojną partyzancką. Zob. ibidem, s. 68.

14 Ibidem, s. 70.

15 R. Jackson, G. Sorensen, op. cit., s. 69.

16 J. Czaputowicz, Teorie stosunków..., s. 70.

${ }_{17}$ S. Burchill, Teorie stosunków międzynarodowych, Warszawa 2006, s. 99.

${ }^{18}$ Należy wspomnieć też o ideologii przeciwstawnej w stosunku do realizmu, a mianowicie o idealizmie. Założeniem idealizmu było twierdzenie, że czynniki zapewniające ład wewnętrzny państwa można przenieść na poziom międzynarodowy. Sytuacja, w której państwa demokratyczne nie będą toczyć ze sobą wojen, przełoży się na powstanie światowego ładu pokojowego, globalnej gospodarki i wytworzenie zinstytucjonalizowanych form współpracy międzynarodowej. Odnosząc się do głównego zagadnienia niniejszego artykułu, czyli problemu bezpieczeństwa, należy pamiętać, że to właśnie idealiści proponowali rozwój koncepcji bezpieczeństwa zbiorowego. Według nich wpływ anarchii na stosunki międzynarodowe mógł być zniwelowany tylko przez stworzenie syste- 
Carr zarzucał idealistom, że działają w „oderwaniu od rzeczywistości”, opierając swe działania na abstrakcyjnych ideach i pragnieniach świata, jaki być może jest przez ludzkość oczekiwany, lecz trudny lub wręcz niemożliwy do osiągnięcia $^{19}$. Przekonania idealistyczne doprowadziły według Carra do sytuacji, w której ,życzenia przeważały nad myśleniem, uogólnienie nad obserwacją i w której niewielką wagę przykłada się do analizy istniejących faktów lub dostępnych środków". Zwracał również uwagę na nieefektywność działalności Ligi Narodów i systemu bezpieczeństwa zbiorowego ${ }^{20}$.

Carr był przekonany (podobnie jak wspomniany wcześniej Machiavelli) o powtarzalności i cykliczności procesów historycznych. Wiedza wynikająca z historii nie jest jednak kumulowaną, dlatego władcy i politycy popełniają błędy podobne do swoich poprzedników. Tak jak wspomniani prekursorzy realizmu, dopatrywał się w naturze ludzkiej praw rządzących światem. Wskazywał, że rządzą zawsze silniejsi, a słabsi powinni im się albo podporządkować, albo zostaną do tego zmuszeni ${ }^{21}$. Wobec powyższego Carra cechuje (obecne m.in. u Hobbesa) przekonanie o anarchiczności systemu międzynarodowego. System międzynarodowy jest anarchiczny, gdyż nie ma w nim żadnej instytucji (a jeśli istnieje, to z reguły jest nieefektywna) posiadającej instrumenty do egzekwowania od państw przestrzegania prawa międzynarodowego ${ }^{22}$.

Podobnie jak inni realiści, Carr obserwuje historię i praktyki zachowania państw ${ }^{23}$, w efekcie czego dochodzi do wniosku, iż dążenie do potęgi jest naturalnym działaniem każdego organizmu państwowego, co nieuchronnie prowadzi do konfliktów międzynarodowych. Możliwości rozwiązywania tych konfliktów dopatrywał się przede wszystkim w tworzeniu równowagi sił między państwami, tak aby jedna potęga mogła hamować drugą, co byłoby najlepszą gwarancją pokoju ${ }^{24}$. Ostatnią cechą twórczości Carra (którą później rozwinie Hans Morgenthau) było

mu bezpieczeństwa zbiorowego, wyrażającego się w istnieniu prawnie legitymizowanej instytucji będącej w stanie narzucić państwom przestrzeganie jej zasad. Zob. R. Tenerowicz, Racjonalistyczne teorie stosunków międzynarodowych. Podobne czy różne?, [w:] Nowe spojrzenia w naukach o polityce, red. W. Jakubowski, A. Dąbrowski, M. Krzysztoszek, t. 1, Warszawa 2012, s. 17.

${ }^{19}$ S. Burchill, op. cit., s. 99.

${ }^{20}$ Carr podawał przykłady niemożności zapobieżenia przez Ligę Narodów interwencji japońskiej w Mandżurii czy włoskiej okupacji Abisynii. Zob. ibidem, s. 100.

${ }^{21}$ J. Czaputowicz, Teorie stosunków..., s. 75.

${ }^{22}$ Realiści wskazywali na wyraźne różnice między systemem politycznym państw (gdzie w relacjach państwo - obywatel istniała egzekucja prawa) a systemem międzynarodowym, gdzie takiej egzekucji de facto nie było.

${ }^{23}$ Carr zwraca na przykład uwagę, że liberalne koncepcje stosunków międzynarodowych, mówiące o harmonizowaniu interesów państw, były tak naprawdę podporządkowane realizacji celów krajów najsilniejszych, uprzywilejowanych. Więcej na ten temat: J. Czaputowicz, Teorie stosunków..., s. 75.

${ }^{24}$ S. Burchill, op. cit., s.104. 
przekonanie o „odrębności” polityki międzynarodowej od innych dziedzin, gdyż - jak wskazywał - nie może ona być podporządkowana np. moralności, a jedynie realizacji interesów państw.

Za głównego teoretyka realizmu stosunków międzynarodowych uznaje się wspomnianego już Amerykanina niemieckiego pochodzenia - Hansa Morgenthau, który w 1948 r. wydał książkę Politics Among Nations: The Struggle for Power and Peace, przez długie lata będącą podręcznikiem dyplomatów amerykańskich (poznanie myśli Morgenthau jest ważne, gdyż - jak wykażę później - Polska musi opierać swe bezpieczeństwo na sojuszu z USA). Realizm współczesny ${ }^{25}$, którego twórcą jest właśnie Morgenthau, podobnie jak myśl Carra, był odpowiedzią na klęskę doktryn idealistycznych dominujących w latach międzywojnia ${ }^{26}$. Książka Morgenthau jest uznawana za fundament teorii realizmu politycznego w stosunkach międzynarodowych, która zdominowała naukę o zachowaniu państw i funkcjonowaniu stosunków między nimi przez lata zimnowojennej rywalizacji ${ }^{27}$.

Myśl Morgenthau cechuje (nieobce wcześniej wymienionym realistom) przekonanie o dążeniu do pozyskania jak największej siły oraz dominacji nad innymi jako sile napędowej społeczności ludzkiej zakorzenionej w biologii i psychologii. Głównymi motywami działania państw są według niego obawa przed utratą stanu posiadania, oczekiwanie korzyści lub chęć budzenia respektu. Uważa też, że $\mathrm{w}$ polityce międzynarodowej potęga jest przeciwstawiana potędze $\mathrm{w}$ walce o supremację i przetrwanie. Potęga, czy też siła państw, była przez Morgenthau postrzegana jako najważniejsza siła sprawcza decydująca o sukcesie i porażce podmiotów w działaniach na arenie międzynarodowej28.

Podobnie jak Carr czy inni prekursorzy myśli realistycznej, Morgenthau uważa, że polityka rządzi się prawami obiektywnymi mającymi swe korzenie w naturze ludzkiej. Prawa te są niezmienne i niezależne od naszej woli, dlatego niepoznanie ich będzie grozić porażką (upadkiem państwa). Aby próbować

${ }^{25}$ J. Czaputowicz podkreśla wielowątkowość i szerokie odwoływanie się realizmu do wielu tradycji. I tak, klasyfikując realizm zgodnie z podziałem chronologicznym, należy wyodrębnić realizm klasyczny (zapoczątkowany wybuchem II wojny światowej i wydaniem przez E. Carra The Twenty Years' Crisis), następnie realizm współczesny (przypadający na lata 1939-1979) i realizm strukturalny (zapoczątkowany wydaniem przez Kennetha Waltza Theory of Internatioal Relations). Inni autorzy, jak Robert Keohane, dzielą realizm na klasyczny i strukturalny, a R. Jackson i G. Sorensen wyróżniają realizm klasyczny, neoklasyczny, strategiczny i neorealizm. Więcej na temat podziałów realizmu zob. J. Czaputowicz, Teorie stosunków..., s. 72-73.

${ }^{26}$ Ibidem, s. 71.

27 J. Więcławski, Hans Morgenthau - realizm klasyczny i jego rekomendacje dla polskiej polityki zagranicznej, „Myśl Ekonomiczna i Polityczna” 2011, nr 3 (34), s. 117-140.

${ }_{28}$ M. Drgas, Systemowe i materialne wyznaczniki potęi państw na przykladzie wojen, „Historia i Polityka” 2011, nr 6 (13), s. 148. 
poprawiać świat, należy działać w zgodzie z siłami natury w sposób realistyczny, a nie kreować oderwane od rzeczywistości koncepcje idealistyczne ${ }^{29}$.

Punktem wyjścia dla myśli realizmu Morgenthau (podobnie jak u Carra) jest pojęcie interesu zdefiniowanego w kategoriach potęgi, siły, co czyni z polityki międzynarodowej sferę niejako niezależną od działania innych sfer, w której motywy i ideologiczne wybory nie są kryteriami działania, ponieważ liczą się przede wszystkim skutki ${ }^{30}$. Morgenthau zwraca też uwagę, że polityki wielkich mocarstw $z$ reguły są niezależne od rozmaitych preferencji moralnych. Założenie to (razem z dogmatem o dążeniu do potęgi) pozwala w sposób racjonalny przewidywać posunięcia państw i mężów stanu, a tym samym unikać błędów zbytniego zaaferowania się kwestiami ideologicznymi ${ }^{31}$.

Idea interesu jest niezależną od okoliczności czasu i miejsca istotą polityki ${ }^{32}$. To interes wyznacza odwieczne standardy oceny działania politycznego i kierowania nim. Interesy państw powinny być stale monitorowane i badane, gdyż nie są dane raz na zawsze, lecz zmieniają się w zależności od kontekstu politycznego i kulturowego. Siła państw nie jest wartością łatwo mierzalną, gdyż oprócz czynników obiektywnych, wymiernych (jak położenie geograficzne, liczba ludności, stan gospodarki czy sił zbrojnych), składają się na nią również czynniki niewymierne (jak jakość przywództwa, charakter narodowy czy morale ludności $)^{33}$. Szczególnie to ostatnie stwierdzenie jest niezwykle ważne dla zapewnienia Rzeczypospolitej bezpieczeństwa ${ }^{34}$.

Morgenthau dokonuje też wyraźnego podziału pomiędzy zasadami moralności a wymogami sukcesu akcji politycznej. Akcja polityczna jest oceniana pod względem konsekwencji, a nie etyki absolutnej. Przywódca polityczny powinien kierować się tylko interesem swego państwa, w odróżnieniu od jednostki, której Morgenthau przyznaje prawo do poświęcenia się w imię wyższych zasad. Realiści stoją na stanowisku, że nie należy odnosić zasad moralnych do działań państw, gdyż te muszą być zawsze odnoszone do okoliczności czasu i miejsca, w których są podejmowane.

29 S. Burchill, op. cit., s. 108.

30 J. Czaputowicz, Teorie stosunków..., s. 78.

${ }^{31}$ H. Morgenthau, Politics Among Nations: the Struggle for Power and Peace, Boston 2005, s. 5.

${ }_{32}$ Morgenthau przytacza twierdzenia Tukidydesa: „Tożsamość interesów jest najpewniejszą więzią pomiędzy państwami i pomiędzy jednostkami”, i Lorda Salisbury: „[...] jedyną trwałą więzią między narodami jest niesprzeczność ich interesów". Za: ibidem, s. 10.

33 J. Czaputowicz, Teorie stosunków..., s. 79.

${ }^{34}$ Bardzo ważnym stwierdzeniem Morgenthau, szczególnie w kontekście Polski i jej uczestnictwa w organizacjach międzynarodowych (jak na przykład Unia Europejska), jest pogląd, że obecnie panujący związek pomiędzy interesem a państwem narodowym jest wytworem historii i jako taki może kiedyś zaniknąć. Nie ma sprzeczności pomiędzy myśleniem realistycznym a stwierdzeniem, że dzisiejszy podział świata oparty na państwach narodowych może w przyszłości zostać zastąpiony przez podmioty, które lepiej będą odpowiadać jego wymogom. Zob. H. Morgenthau, op. cit., s. 12. 
Bardzo ważnym punktem myśli Morgenthau jest przekonanie, że państwa cechuje przedstawianie swych aspiracji, celów i działań w taki sposób, aby wykazać ich zgodność z uniwersalnymi prawami moralnymi. Według niego wszystkie narody są wystawiane na pokusę (której długo nie są w stanie się opierać), aby używać abstrakcyjnych moralnych celów i idei dla realizacji swych partykularnych interesów i aspiracji ${ }^{35}$.

Morgenthau zauważa również, że to właśnie teoria interesu postrzeganego w kategorii potęgi chroni nas od moralnej przesady i politycznej nieroztropności. Pozwala na dokonywanie oceny naszego zachowania i innych państw oraz (w następstwie) prowadzenie polityki szanującej interesy partnerów i realizację naszych postanowień ${ }^{36}$. Dostrzega także, czym różni się realizm polityczny od innych szkół teorii stosunków międzynarodowych ze względu na przyjęcie zasady pewnej autonomiczności sfery polityki i odrębności praw nią rządzących ${ }^{37}$. Realizm opiera się na niezgodzie na narzucenie sferze politycznej myślenia czy to w zgodzie z zasadami moralności, czy literą prawa. Nadrzędną kategorią jest - jak już wcześniej wielokrotnie wspomniano - pojęcie siły, potęgi i interesu narodów ${ }^{38}$.

Dopełnieniem doktrynalnych podstaw myśli realistycznej (w odniesieniu do bezpieczeństwa Polski) musi być omówienie zasad neorealizmu, którego twórcą był Kenneth Waltz. Swoją koncepcję przedstawił w książce The Theory of International Politics opublikowanej w 1979 r. Mówiąc o koncepcji neorealistycznej, należy pamiętać o czasie, w którym ona „dojrzewała”. Były to lata 70. i 80., których wydarzenia zdawały się potwierdzać wyższość teorii realizmu nad teoriami liberalnymi i globalistycznymi. Doszło przede wszystkim do zmarginalizowania instytucji międzynarodowych, państwa prowadziły własne polityki, toczono wojny i trwał wyścig zbrojeń między blokiem wschodnim a zachodnim ${ }^{39}$.

Do sformułowania koncepcji neorealistycznych skłoniła Waltza refleksja nad zachowaniem USA i ZSRR w trakcie zimnowojennej rywalizacji. Nie będzie przesadą stwierdzenie, iż państwa te różniło prawie wszystko, począwszy od ideologii, ustroju i warunków społecznych, a skończywszy na gospodarce. Obydwa kraje w swej polityce zagranicznej postępowały jednak zaskakująco podobnie. Budowały one swe strategiczne potęgi, pomnażały arsenały nuklearne i konwencjonalne oraz wykorzystywały strefy wpływów dla realizacji interesów ${ }^{40}$. Waltz dochodzi do wniosku, iż źródło takiego stanu rzeczy tkwi w ograniczeniach syste-

\footnotetext{
35 Ibidem.

36 Ibidem, s. 13.

37 J. Czaputowicz, Teorie stosunków..., s. 79.

38 H. Morgenthau, op. cit., s. 13.

39 J. Czaputowicz, Teorie stosunków..., s. 176.

40 S. Burchill, op. cit., s. 122.
} 
mowych nakładanych na państwa wzajemnie, które ujednolicają ich zachowania na arenie międzynarodowej ${ }^{41}$, inaczej mówiąc - na strukturze systemu międzynarodowego, w której przychodzi działać państwom ${ }^{42}$.

Teorię neorealizmu - jako myśl wywodzącą się bezpośrednio z koncepcji realistycznych - łączy z nimi bardzo dużo. Przede wszystkim wykorzystuje ona koncepcję anarchii międzynarodowej, skupia się wyłącznie na państwach i polityce siły oraz twierdzi, że główną troską krajów i narodów jest bezpieczeństwo i przetrwanie ${ }^{43}$.

Jak zaznaczono, w centrum neorealizmu Waltza stoi system międzynarodowy składający się z elementów, czyli państw i struktury zarządzającej relacjami pomiędzy nimi. Strukturą tą jest międzynarodowa anarchia ${ }^{44}$. Według Waltza anarchia międzynarodowa, jako naczelna zasada organizująca system międzynarodowy, prowadzi do prymatu kwestii bezpieczeństwa i warunkuje zasadę samopomocy (tzw. self-help) jako najbardziej realistycznej i racjonalnej zasady zachowań państw. Stanem naturalnym dla międzynarodowej anarchii jest fakt, iż państwa nigdy nie mogą być pewne trwałości międzynarodowych umów i zobowiązań. Taki stan rzeczy warunkowany jest tym, iż nie istnieje żadna instytucja zdolna do ich egzekucji ${ }^{45}$, co łączy teorie Waltza z przekonaniami Hobbesa czy Carra. To właśnie struktura systemu międzynarodowego jest katalizatorem zachowań państw, wymusza pewne zachowania, inne nagradza, a jeszcze inne karze ${ }^{46}$. Struktura ta jednak poddaje się oddziaływaniu państw, które ją kształtują ${ }^{47}$.

Neorealizm Waltza opiera się na założeniu, iż różnice między państwami wynikają z ich mocno odmiennych zdolności do realizacji swych interesów. W doktrynie struktury systemu najważniejsze znaczenie mają mocarstwa. Według Waltza możliwe jest osiągnięcie względnej równowagi sił pomiędzy tymi państwami, lecz nigdy nie da się stuprocentowo wykluczyć wojny. Waltz dokonuje również rozróżnienia struktury systemu międzynarodowego na systemy bipolarne (czas zimnowojennej rywalizacji między USA i ZSRR) i multipolarne, które istniały zarówno przed, jak i po II wojnie światowej. Należy odnotować

41 Ibidem, s. 123.

${ }^{42} \mathrm{~W}$ tym miejscu należy wskazać różnicę dającą się zaobserwować pomiędzy realizmem klasycznym a neorealizmem. W przeciwieństwie do realizmu klasycznego, szukającego wyjaśnień procesów międzynarodowych w charakterze i celach poszczególnych państw, neorealizm skupia się na badaniu struktury systemu międzynarodowego. Zob. A. Heywood, op. cit., s. 102.

${ }^{43}$ R. Jackson, G. Sorensen, op. cit., s. 78-79.

${ }^{44}$ Ł. Fijałkowski, A. Polus, Krytyczna analiza wybranych aspektów teorii polityki międzynarodowej Kennetha Waltza, „Wrocławskie Studia Politologiczne” 2012, nr 13, s. 63.

${ }^{45}$ Ibidem.

46 J. Czaputowicz porównuje tę sytuację do struktury wolnego rynku w ekonomii.

47 J. Czaputowicz, Teorie stosunków..., s. 179. 
przekonanie tego badacza, iż system bipolarny jest bardziej bezpieczny ${ }^{48} \mathrm{i}$ daje większą gwarancję pokoju, gdyż w sytuacji istnienia tylko dwóch wielkich mocarstw, obydwa będą dążyć do utrzymania status quo ${ }^{49}$.

\section{STOSUNKI Z ROSJĄ I STANAMI ZJEDNOCZONYMI}

Jak wspomniano we wstępie niniejszego artykułu, odwiecznym problemem narodu polskiego było zapewnienie bezpieczeństwa dla kraju. Wpływało na to przede wszystkim położenie geopolityczne, usytuowanie pomiędzy Niemcami i Rosją jako dwiema niezwykle ekspansywnymi kulturami oraz fakt słabości gospodarczej i militarnej.

Zgodnie z przedstawioną wcześniej myślą realistyczną należy stwierdzić, iż głównym celem, racją stanu Polski jest i będzie w tzw. przewidywalnym czasie utrzymanie bezpieczeństwa militarnego, terytorialnego i gospodarczego oraz rozwój własnych sił. W oparciu o przedstawione wcześniej założenia realizmu należy więc wskazać siły, państwa, które mają od Polski większy potencjał, reprezentują sprzeczne interesy ${ }^{50}$ i jako takie mogą zagrozić bezpieczeństwu państwa polskiego.

Niewątpliwie największym zagrożeniem dla bezpieczeństwa Rzeczypospolitej, jej stabilności i pozycji międzynarodowej jest Federacja Rosyjska. Obecnie nie jest to zagrożenie bezpośrednie, lecz polityka Rosji, niestroniąca od używania siły i pogwałceń prawa międzynarodowego, powinna skłaniać Polskę do pewnej redefinicji swego systemu bezpieczeństwa. Rosja jest w mojej ocenie idealnym przykładem realistycznego podejścia do polityki zagranicznej w kontekście realizacji interesu państwa. Mimo tego, że pozostaje związana w systemie międzynarodowym wieloma traktatami i przynależy np. do Rady Europy czy OBWE, a także jest stałym członkiem Rady Bezpieczeństwa ONZ, prezentuje na tyle silny potencjał, aby w zgodzie z przedstawionymi postulatami realizmu nie przestrzegać prawa międzynarodowego. Takie zachowanie jest skutkiem nie tyle braku organizacji mających na celu utrzymanie światowego bezpieczeństwa, lecz (jak zauważali Hobbes czy Carr) braku posiadania przez nie instrumentów skutecznie egzekwujących prawo międzynarodowe. Dowodem jest oczywiście postępowanie Rosji w trakcie tzw. Euromajdanu czy pogwałcenie prawa międzynarodowego w postaci aneksji Krymu w 2014 r. Dlatego Polska, która po 1989 r. dokonała wyboru strategicznego związania się z tzw. Światem Zachodnim skupionym wokół

${ }^{48}$ Neorealiści są zaniepokojeni propozycją systemu jednobiegunowego, w którym rolę nadrzędną odgrywałoby USA. Więcej zob. S. Burchill, op. cit., s. 132-134.

${ }^{49}$ R. Jackson, G. Sorensen, op. cit., s. 78.

50 Sprzeczności interesów mogą występować również z wieloma mniejszymi państwami, ale należy obawiać się tylko dużych, gdyż zgodnie z doktryną realizmu mniejsi i słabsi muszą się podporządkować. 
Stanów Zjednoczonych, powinna postrzegać Rosję jako główne zagrożenie dla swego bezpieczeństwa.

Zagrożenie ze strony Rosji dla bezpieczeństwa Rzeczypospolitej wynika przede wszystkim z rozbieżności interesów obu państw oraz z tego, iż Rosja jest państwem posiadającym o wiele większą potęgę od Polski. Pamiętając zasady doktryny realizmu, należy ocenić siły Rosji i spróbować zdefiniować jej interesy, które są sprzeczne z koncepcją bezpieczeństwa państwa polskiego.

Faktem jest, że Rosja należy do jednych z najpotężniejszych państw świata. Świadczy o tym jej armia ${ }^{51}$, największy na świecie potencjał broni nuklearnej, położenie geograficzne, rezerwy walutowe (500 mld dolarów w 2015 r.) czy wreszcie niezwykle często wykorzystywany przez Rosję we wpływaniu na inne państwa atut, czyli bogactwa naturalne ${ }^{52}$. Wydawałoby się, że ma ona wszelkie warunki do tego, aby być jednym z głównych światowych rozgrywających. Jak zauważa Jacek Więcławski, ocenienie potęgi rosyjskiej jest jednak zadaniem wysoce problematycznym ${ }^{53}$. Federacja Rosyjska jest również krajem nękanym wieloma problemami strukturalnymi wynikającymi jeszcze z czasów ZSRR. Gospodarka Rosji (w dzisiejszym świecie państwa chcące odgrywać znaczącą rolę muszą posiadać nowoczesną gospodarkę), oprócz sektora energetycznego, jest w stanie stagnacji, jeśli nie rozkładu. Rozwój blokuje wszechobecna korupcja ${ }^{54}$, brak konkurencyjności i zbiurokratyzowanie procedur. Ponadto ogromnym problemem Rosji w nadchodzących latach będzie spadek liczby ludności oraz wzrost wyznawców islamu, co może powodować niestabilność wewnętrzną ${ }^{55}$.

Wspomniany wcześniej atut w postaci posiadania surowców energetycznych może równie szybko okazać się przekleństwem, gdyż nie tylko uzależnia rosyjską gospodarkę od cen ropy i gazu na światowych rynkach, ale także od tego, czy potencjalni odbiorcy po prostu zechcą je od Rosji kupować. To zagrożenie jest tym bardziej realne, iż niedawno dzięki „rewolucji łupkowej” USA stały się eksporterem gazu i możliwość, że państwa europejskie będą go kupować z tego kierunku jest bardzo realna ${ }^{56}$. Należy stwierdzić, że mimo wszystkich problemów i słabości Rosji jest ona w dalszym ciągu państwem dysponującym wystarczającym potencjałem, aby destabilizować i zagrażać bezpieczeństwu Polski.

${ }^{51}$ Armia Rosji jest uznawana za drugą pod względem potencjału na świecie (po amerykańskiej). Zob. http://globalfirepower.com [data dostępu: 10.03.2016].

52 A. Balcer, K. Wóycicki, Polska na globalnej szachownicy, Warszawa 2014, s. 295.

53 J. Więcławski, op. cit., s. 131.

${ }^{54} \mathrm{~W}$ rankingu skorumpowania państw z 2014 r. Corruptions Perceptions Index, przygotowywanym przez Transparency International, Rosja zajmuje 136. miejsce na 175 państw (Polska - 35.).

Zob. www.transparency.org [data dostępu: 10.03.2016].

${ }^{55}$ Więcej o słabościach Rosji zob. A. Balcer, K. Wóycicki, op. cit., s. 296-297.

56 Ibidem, s. 297. 
Postępując w zgodzie z kanonami myśli realistycznej, należy również skupić się na ocenie siły Rzeczypospolitej w kontekście ewentualnych konfliktów z Federacją Rosyjską. Pomimo tego, że Polska może się pochwalić stosunkowo zdrową i silną gospodarką, która jako jedyna z państw UE nie zanotowała recesji w latach kryzysu finansowego zapoczątkowanego w 2007 r., to jednak jest to gospodarka o wiele mniejsza od rosyjskiej ${ }^{57}$. Pod względem siły militarnej Polska również nie jest w stanie równać się z Rosją. W rankingu Globalfirepower, mierzącym potencjał wojskowy państw, Rosja zajmuje drugie (po USA) miejsce, natomiast Polska $-19 .{ }^{58}$ Armia naszego kraju liczy około 120 tys. ${ }^{59}$ żołnierzy i nie dysponuje odpowiednią ilością nowoczesnego uzbrojenia (nie mówiąc o broni atomowej), aby skutecznie przeciwstawić się Rosji ${ }^{60}$. Optymizmem nie napawa też prognoza rozwoju demografii Polski. Z obecnej liczby 38,1 mln obywateli ludność Polski ma się skurczyć (według optymistycznych prognoz) do $36,8 \mathrm{mln}$ w $2030 \mathrm{r}^{6}{ }^{61}$

Znając podstawowe elementy sił Polski i Rosji, jako główne czynniki decydujące o akcjach państw na arenie międzynarodowej, należy przejść do definicji ich interesów oraz możliwych konfliktów z nich wynikających. W mojej ocenie interesy Rosji już od upadku ZSRR były niezmienne. Należało do nich przede wszystkim utrzymanie jak największych wpływów w obszarze dawnego bloku wschodniego i wasalizacja byłych republik Związku Radzieckiego. Rosja pogrążona w „Jelcynowskiej smucie” nie była jednak dostatecznie silna, aby skutecznie przeciwstawić się chociażby wejściu Polski do NATO i UE. Ryszard Zięba trafnie zauważa, iż od lat 2006-2007 rozpoczął się proces istotnej redefinicji polityki zagranicznej i bezpieczeństwa Federacji Rosyjskiej. Nowe koncepcje zostały wyrażone w wielu przemówieniach rosyjskich przywódców oraz w przyjętych dokumentach programowych ${ }^{62}$.

Wraz ze wzrostem swej siły Rosja dążyła i dąży do istotnej zmiany lub nawet likwidacji wytworzonego po zimnej wojnie unipolarnego systemu międzynarodowego opartego na potędze USA jako ,światowego policjanta”. Istotą zmiany jest według Rosji włączenie jej z powrotem i na równych warunkach do grona

${ }^{57}$ W 2014 r. wartość gospodarki Federacji Rosyjskiej wynosiła 1 860,598 mln dolarów, a Polski - $548003 \mathrm{mln}$ dolarów. Zob. http://data.worldbank.org/data-catalog/GDP-ranking-table [data dostępu: 10.03.2016].

${ }_{58}$ Zob. http://globalfirepower.com [data dostępu: 10.03.2016].

59 R. Zięba, Uwarunkowania polityki zagranicznej Polski na początku drugiej dekady XXI wieku, „Stosunki Międzynarodowe - International Relations” 2011, nr 1-2, s. 14.

${ }^{60}$ Rosja w 2014 r. posiadała 766000 aktywnego personelu wojskowego. Zob. http://globalfirepower.com [data dostępu: 10.03.2016].

${ }^{61}$ Zob. Prognoza ludności na lata 2008-2035, GUS, Warszawa 2009, s. 188.

${ }^{62}$ Mowa tu o takich dokumentach, jak Koncepcja polityki zagranicznej Federacji Rosyjskiej z dnia 12 lipca 2008 r., Strategia bezpieczeństwa narodowego Federacji Rosyjskiej z dnia 12 maja 2009 r. i Doktryna wojenna Federacji Rosyjskiej z dnia 5 lutego 2010 r. Zob. R. Zięba, Uwarunkowania..., s. 30-31. 
największych światowych mocarstw (obok USA i Chin), mogących współdecydować o losach świata ${ }^{63}$. Niewątpliwe jest też, iż Rosja chciałaby mieć wpływ na politykę Polski. Oczywiście traktuje ona Polskę inaczej niż kraje byłego ZSRR, ale stara się wytworzyć sytuację, w której (np. przez „szantaż energetyczny”) będzie mogła wywierać na nasz kraj presję i w ten sposób realizować swe interesy.

Ponadto relacje z Rosją mogą być trudne i nieprzewidywalne, gdyż - jak już wspomniałem - postępując w zgodzie z myślą realizmu, ucieka się ona do stosowania siły, a nadrzędną dla niej sprawą jest także realizacja własnego interesu. Będzie go realizować bez zwracania uwagi na graczy słabszych (do których bez wątpienia należy Polska) czy na wiążące ją układy prawa międzynarodowego. Wszystkie te działania Rosji mogą mieć pośrednie lub bezpośrednie negatywne implikacje dla bezpieczeństwa polskiego i są one sprzeczne ze wskazanymi poniżej polskimi interesami. Pierwszym i najważniejszym konfliktem interesów między Polską a Rosją jest oczywiście spór o przyszłość byłego obszaru postradzieckiego. Wiedząc, że Rosja dąży do osiągnięcia kontroli nad państwami byłego ZSRR, należy stwierdzić, że jest to działanie całkowicie niezgodne z polską racją stanu. Głównym celem Polski, fundamentalnym dla jej bezpieczeństwa, jest przyciąganie Ukrainy do struktur świata zachodniego. Obecność Ukrainy w tych strukturach oznacza wyrwanie jej z rosyjskiej strefy wpływów i doprowadzenie do fundamentalnego osłabienia Federacji Rosyjskiej, co poskutkuje brakiem możliwości wywierania przez nią wpływu na Polskę, czyli zwiększeniem polskiego bezpieczeństwa narodowego ${ }^{64}$.

Polska jest bardzo zainteresowana powiększaniem obszaru europejskiej współpracy (czy nawet UE) na wschód, również na takie kraje, jak Białoruś, Mołdawia czy Gruzja. Z przyczyn wskazanych różnic sił i potencjałów między Polską a Rosją, nasz kraj skazany jest prowadzić powyższą politykę w oparciu o wzmocnienie wynikające z członkostwa w Unii Europejskiej ${ }^{65}$. Temu celowi miało służyć stworzenie inicjatywy Partnerstwa Wschodniego ${ }^{66}$. Niestety, praktyka pokazała, iż jedynie Polska i Szwecja były państwami skłonnymi do realizowania pogłębionej współpracy z państwami byłego ZSRR ${ }^{67}$. Takie kraje, jak Niemcy czy Francja są o wiele bardziej zainteresowane robieniem z Rosją dochodowych in-

${ }^{63}$ A. Balcer, K. Wóycicki, op. cit., s. 294.

${ }^{64}$ R. Zięba, Implikacje stosunków polsko-amerykańskich dla polityki zagranicznej Polski, „Przegląd Politologiczny” 2015, nr 2, s. 9.

${ }^{65}$ Aby móc realizować swe interesy, Rosja, która jest nieporównywalnie słabsza (pod względem gospodarczym, politycznym czy społecznym) od Unii Europejskiej, będzie starać się próbować rozbić jej jedność i solidarność, próbując zawierać dwustronne układy z najsilniejszymi państwami oraz wbijać klin pomiędzy tzw. starą i nową Unię. Zob. J. Więcławski, op. cit., s. 123.

${ }_{66}$ Partnerstwo Wschodnie - program unijnej polityki sąsiedztwa mający na celu intensyfikację współpracy pomiędzy UE a państwami byłego ZSRR.

${ }_{67}$ R. Zięba, Uwarunkowania..., s. 29. 
teresów i wolałyby nie angażować się z nią w potencjalny konflikt (tym bardziej, że obszar postsowiecki nie leży w sferze ich bezpośredniego zainteresowania). W mojej ocenie w wyniku ukraińskiej „Eurorewolucji” istnieje pewna nadzieja na zmianę podejścia państw Europy Zachodniej do Rosji i integracji obszaru postsowieckiego z UE, będzie to jednak proces niezwykle długotrwały, trzeba będzie przezwyciężyć opór wielu środowisk, których interesy zostałyby zagrożone ewentualnym konfliktowaniem się z Federacją.

Sytuacja konfliktu interesów z Rosją skutkowała potrzebą szukania gwaranta polskiego bezpieczeństwa na zewnątrz. Do tej pory takim gwarantem wydawały się być NATO i art. 5 Traktatu Północnoatlantyckiego ${ }^{68}$ oraz Unia Europejska. W mojej ocenie kryzys ukraiński pokazał, że ani NATO, ani UE - będące zbiorowościami państw posiadającymi przede wszystkim własne interesy oraz (zgodnie ze wspomnianym twierdzeniem Rousseau) przedkładające je nad interesy kolektywne - nie będą w stanie zapewnić Polsce bezpieczeństwa w sposób nas satysfakcjonujący. Ponadto wcześniej opisane zachowania Rosji i dość „ospałe” reakcje społeczności międzynarodowej w stosunku do nich pokazują, że Polska nie może pokładać wielkich nadziei w zapisach traktatów międzynarodowych. Należy znaleźć takie państwo, które byłoby odpowiednio silne, aby zapewnić nam bezpieczeństwo, ale również takie, z którym łączyłaby Polskę wspólnota interesów. Według wybitnego amerykańskiego politologa i stratega Georga Friedmana jedyną taką siłą są dziś USA. Podobnie jak Polska, USA z niechęcią patrzą na wzrost potęgi i ekspansjonizmu Rosji w obszarze byłego ZSRR (w przeciwieństwie do wspomnianych państw Europy Zachodniej), co więcej - Friedman uważa, że USA są przekonane o problemach wynikających z rozbieżnych interesów krajów NATO (oraz wynikającej z nich niemożności szybkiego działania) i będą skupiać się na rozwijaniu dwustronnych relacji z Polską ${ }^{69}$.

Mieczysław Stolarczyk zwraca uwagę, że „Bezpieczeństwo Polski w znacznym stopniu determinowane jest stanem stosunków amerykańsko-rosyjskich"70. Stosunki te (zwłaszcza po okresie tzw. resetu ${ }^{71}$ ), znalazły się po wydarzeniach ukraińskich na krawędzi nowej zimnej wojny i Polska powinna to wykorzystać. Wydaje się, że w amerykańskich kręgach rządowych dojrzewa koncepcja stworzenia bloku państw, który miałby na celu powstrzymywanie ekspansji Rosji. Taki blok miałby opierać się na będących członkami NATO Polsce, Rumunii i Turcji, a także na mniejszych państwach, jak Sło-

${ }^{68}$ Art. 5 Traktatu Północnoatlantyckiego nakłada na państwa sojusznicze obowiązek kolektywnej obrony.

${ }^{69}$ www.rodaknet.com/rp_art 5969_czytelnia_strategia_polski_george_friedman.htm [data dostępu: 10.03.2016].

${ }^{70}$ R. Zięba, Implikacje..., s. 9.

71 Tzw. reset był inicjatywą administracji prezydenta USA Baracka Obamy i miał na celu poprawę stosunków z Federacją Rosyjską. 
wacja, Węgry czy państwa bałtyckie. Stworzenie takiego bloku leży głęboko w amerykańskim interesie ${ }^{72}$, gdyż przesuwałoby linię powstrzymywania Rosji na wschodnią granicę NATO (wobec zimnowojennej granicy niemieckoniemieckiej) oraz tworzyłoby bufor zapobiegający połączeniu się potęgi niemieckiej i rosyjskiej, co byłoby dla USA bardzo niebezpieczne (o stosunkach niemiecko-rosyjskich $\mathrm{w}$ dalszej części artykułu). W amerykańskim interesie leży też utrzymanie jedności UE, dlatego niepokojące dla USA zawsze będą perspektywy dezintegracji (kryzys strefy euro) czy renacjonalizacji polityk państw (możliwe wyjście Wielkiej Brytanii z UE) ${ }^{73}$.

Amerykanie oczekują od Europy większego i bardziej zdecydowanego zaangażowania się w sprawy porządku świata i polityki bezpieczeństwa. Wobec przewidywanej niechęci wielu państw europejskich do takiej postawy (przede wszystkim Niemiec i Francji), aktywna Polska skupiająca wokół siebie wspomniane już państwa „nowego międzymorza” może stać się regionalnym liderem $i$ atrakcyjnym partnerem dla USA $^{74}$.

Dowodem na wspólnotę interesów między Polską a Ameryką były i są działania obydwu państw na obszarze byłego Związku Sowieckiego. Oba kraje popierały nadanie Gruzji i Ukrainie perspektywy członkostwa w NATO ${ }^{75}$ (zablokowane przez Niemcy i Francję) i wspierały tzw. kolorowe rewolucje ${ }^{76}$. Ponadto to właśnie od Polski i USA nowe władze ukraińskie otrzymały największe wsparcie w trakcie wydarzeń na Majdanie w $2014 \mathrm{r}^{77}$

Oczywiście w relacjach z USA należy się całkowicie wyzbyć mitologizowania tego państwa. Opieranie się na abstrakcyjnych koncepcjach unikalnych więzi łączących USA i Polskę jest kompletnie niezgodne z założeniami doktryny realistycznej ${ }^{78}$. Sojusz z USA należy tworzyć w oparciu o polityczny realizm, który mówi, że Stany Zjednoczone przyjdą Polsce z pomocą wtedy, gdy będzie to leżało $\mathrm{w}$ ich interesie i do wytworzenia takiego stanu rzeczy Polska powinna dążyć. Oprócz wyżej wymienionej wspólnoty interesów między Polską a USA do sytuacji, w której będą one musiały przyjść Polsce z pomocą, może doprowadzić umiejscowienie interesów amerykańskich w Polsce. Takie działanie może się zrealizować w postaci instalacji elementów

${ }^{72}$ George Friedman: Nie macie słabości Rosji i Niemiec. Polska jeszcze będzie potęga, http:// wiadomosci.dziennik.pl/opinie/artykuly/460968,george-friedman-o-polityce-rosji-przyszloscipolski-i-jej-roli-w-europie.html [data dostępu: 10.03.2016].

73 A. Balcer, K. Wóycicki, op. cit., s. 322.

74 Ibidem.

75 J. Czaputowicz, Polityka bezpieczeństwa Polski - między samodzielnościa a europeizacja, „e-Politikon. Kwartalnik Naukowy Ośrodka Analiz Politologicznych Uniwersytetu Warszawskiego" 2013, nr 6, s. 26.

${ }^{76}$ Mowa tu o Rewolucji Róż z 2003 r. w Gruzji i Pomarańczowej Rewolucji z 2004 r. na Ukrainie.

77 R. Zięba, Implikacje..., s. 10.

${ }^{78}$ A. Balcer, K. Wóycicki, op. cit., s. 318. 
tarczy antyrakietowej w miejscowości Redzikowo. Tarcza, która ma służyć przede wszystkim ochronie terytorium USA przed pociskami dalekiego zasięgu, stanie się ważnym elementem bezpieczeństwa tego państwa. USA nie będą mogły pozwolić sobie na zachwianie się tego elementu i (według doktryny realistycznej) będą niejako zmuszone do zaangażowania się w bezpieczeństwo i stabilność Polski ${ }^{79}$.

Mówiąc o zaangażowaniu się USA w polskie bezpieczeństwo, trzeba też pamiętać, czego kraj ten oczekuje od nas. USA chcą, aby Polska była przede wszystkim państwem pełniącym rolę przykładu pomyślnej transformacji demokratycznej, stabilizatora sytuacji w regionie i pomocnika USA na arenie międzynarodowej. W mojej ocenie nie jest to cena wygórowana, aby móc domagać się od USA zaangażowania w polskie bezpieczeństwo.

Należy również pamiętać, że bez własnego zaangażowania w bezpieczeństwo i zdawanie się tylko na wykazaną wspólnotę interesów z Ameryką, Polska może popełnić kardynalny błąd. Przede wszystkim Rzeczpospolita musi doprowadzić do sytuacji, w której jakikolwiek atak czy próba destabilizacji kraju będą nieopłacalne dla potencjalnego agresora. Truizmem jest stwierdzenie, iż potrzebna jest w tym celu armia wystarczająco silna do zadania ciężkich strat przeciwnikowi i będąca w stanie utrzymać kluczowe punkty kraju do czasu przyjścia sojuszników z pomocą. Trzeba dysponować armią nowoczesną, co jest w stanie zapewnić dziś tylko współpraca z USA ${ }^{80}$.

Może zdarzyć się też sytuacja, w której polska armia zostanie pokonana, a sojusznicy nie przyjdą z pomocą. Pamiętając o recepcie Jana Jakuba Rousseau stworzonej dla państw otoczonych przez silnych sąsiadów, należy stwierdzić, iż swoistą polisą ubezpieczeniową powinno być utworzenie (bardzo dziś popularne w dyskursie publicznym) armii terytorialnej, odpowiednika amerykańskiej Gwardii Narodowej $^{81}$. Istnienie takich sił byłoby następnym elementem odstraszającym potencjalnych przeciwników, którzy co prawda byliby w stanie kraj zająć, ale nie mogliby go spacyfikować ${ }^{82}$. Mając na uwadze Rosję jako główne zagrożenie dla bezpieczeństwa naszego kraju, trzeba pamiętać, że Związek Sowiecki podczas interwencji w Afganistanie został pokonany właśnie przez oddziały partyzantki nękającej siły radzieckie. Świadomość kosztów operacji afgańskiej jest w Rosji niezwykle silna i fakt ten również powinien zostać wykorzystany przez Polskę przy tworzeniu oddziałów obrony terytorialnej. Następną ważną rzeczą związaną z obroną terytorialną, podkreślaną np. przez Morgenthau, jest krzewienie postaw patriotycznych i budowanie wysokiego morale narodowego, tak aby obywatele czuli się związani z państwem i chcieli uczestniczyć w inicjatywach proobronnych.

79 J. Czaputowicz, Polityka bezpieczeństwa Polski..., s. 37-38.

80 A. Balcer, K. Wócicki, op. cit., s. 318.

${ }^{81}$ Zob. http://obronanarodowa.pl [data dostępu: 10.03.2016].

82 J. Czaputowicz, Polityka bezpieczeństwa Polski..., s. 39. 
Kolejnym aspektem bezpieczeństwa Polski, powiązanym z zagrożeniem rosyjskim, jest zachowanie się Niemiec. Przez przeszło 25 lat od zjednoczenia Niemcy stały się europejską potęgą gospodarczą i polityczną. Nic w Europie nie dzieje się, jeżeli nie bez zgody, to przynajmniej bez sprzeciwu ze strony Republiki Federalnej. Nie ulega wątpliwości, że Polska jest związana z Niemcami bardzo silnymi stosunkami zarówno politycznymi, jak i ekonomicznymi. Partnerstwo niemiecko-polskie jest bardzo głębokie ${ }^{83}$, a stosunki między państwami są chyba najlepsze w historii. Taki stan rzeczy sprawia, że zachodnia granica Polski jest dzisiaj stabilna i bezpieczna (co jest sytuacją dość unikalną w dziejach naszego kraju). To właśnie Niemcy jednak pozostają dziś dla Polski wielką niewiadomą. Przede wszystkim dlatego, że nawet w Niemczech nie ma w tym momencie konsensusu dotyczącego roli, jaką miałby odgrywać ten kraj w Europie. Jedne środowiska są zafascynowane wzrostem niemieckiej potęgi i widzą Niemcy jako „europejskie mocarstwo centralne” skupiające się przede wszystkim na własnych interesach, drugie zaś chciałyby, aby Niemcy - jako jedyne dziś państwo zdolne przewodzić Europie - wzięło za nią odpowiedzialność jako wspólnotę 28 państw.

Postawa Niemiec może rodzić pewne problemy. Przede wszystkim Niemcy stały się swoistym zakładnikiem swojego sukcesu. Charakteryzuje je gospodarka wybitnie nastawiona na eksport, co rodzi dwie implikacje: ogromną potrzebę surowców i ogromną potrzebę rynków zbytu. Obydwie potrzeby wydaje się spełniać Rosja, posiadająca (jak już wspomniano) ogromne złoża surowców energetycznych i dysponująca prawie 150-milionowym rynkiem. Wobec powyższego prawdopodobna wydaje się być sytuacja, w której Niemcy (gdzie wpływ eksporterów na politykę jest bardzo duży $)^{84}$ będą musiały utrzymywać ścisłą współpracę z Rosją, nawet za cenę pewnych koncesji w zakresie bezpieczeństwa europejskiego ${ }^{85}$ (nieangażowanie się na Ukrainie czy sprzeciw wobec amerykańskiej obecności w Europie Centralnej).

W mojej ocenie Polska nie powinna obawiać się Niemiec. Oczywiście, w myśl założeń doktryny realistycznej, należy pamiętać o historii i wyciągać z niej wnioski. Od niemieckiego pragmatyzmu w stosunkach z Rosją, spowodowanego troską o gospodarkę do wspierania jej w destabilizacji Europy Centralnej, droga jest daleka. Dlatego jestem zdania, że Niemcy, mimo silnych gospodarczych związków z Rosją, pozostaną wiernym sojusznikiem w ramach NATO i UE, co będzie też gwarantować obecność 37 tys. amerykańskich żołnierzy na ich terytorium ${ }^{86}$.

${ }^{83}$ A. Balcer, K. Wóycicki, op. cit., s. 178.

${ }^{84}$ A. Kwiatkowska-Drożdż, Mocarstwo Pragmatyczne, „Nowa Europa” 2012, nr 1 (12), s. 159.

${ }^{85}$ Ibidem, s. 161.

${ }^{86}$ Zob. Total Military Personnel and Dependent End Strength by Service, Regional Area, and Country, Defense Manpower Data Center, June 30, 2015. 


\section{UWAGI KOŃCOWE}

Nie ulega wątpliwości, że zapewnienie Polsce bezpieczeństwa będzie nie tylko dla decydentów, ale i całego narodu zadaniem bardzo trudnym. Niniejszy artykuł dowodzi, że nie jest to zadanie niemożliwe do spełnienia. Należy unikać zbytniego opierania się na instytucjach i traktatach międzynarodowych, gdyż jak mówi realizm - państwa zawsze będą kierować się swym interesem i w tym celu nie zawahają się złamać prawa międzynarodowego. Punktem wyjściowym powinno być oparcie się na wskazanej realistycznej analizie sił i interesów poszczególnych państw oraz zawieranie sojuszy z tymi, z którymi te interesy są tożsame i które dysponują odpowiednią potęgą, aby realizując swą rację stanu, realizować też postulat zapewnienia bezpieczeństwa Polsce. Na chwilę obecną jedynym takim państwem są Stany Zjednoczone. Kluczem do relacji z tym krajem powinno być wskazywanie wspólnoty interesów łączących go z Polską (czy szerzej - krajami Europy Centralnej) i przez to angażowanie USA w bezpieczeństwo naszego kraju. Według doktryny realizmu Polska powinna dysponować nie tylko silną armią zawodową, ale i dobrze wyszkolonymi, licznymi oddziałami obrony terytorialnej. Tworzyłoby to sytuację, w której okupacja naszego kraju stałaby się dla potencjalnego agresora nieopłacalna, co wydatnie przyczyniłoby się do wzmocnienia bezpieczeństwa Rzeczypospolitej.

\section{BIBLIOGRAFIA}

Balcer A., Wóycicki K., Polska na globalnej szachownicy, Warszawa 2014.

Burchill S., Teorie stosunków międzynarodowych, Warszawa 2006.

Czaputowicz J., Polityka bezpieczeństwa Polski - między samodzielnościa a europeizacja, „e-Politikon. Kwartalnik Naukowy Ośrodka Analiz Politologicznych Uniwersytetu Warszawskiego" 2013, nr 6 .

Czaputowicz J., Teorie stosunków międzynarodowych: krytyka i systematyzacja, Warszawa 2008.

Drgas M., Systemowe i materialne wyznaczniki potęgi państw na przykładzie wojen, „Historia i Polityka" 2011, nr 6 (13).

Fijałkowski Ł., Polus A., Krytyczna analiza wybranych aspektów teorii polityki międzynarodowej Kennetha Waltza, „Wrocławskie Studia Politologiczne” 2012, nr 13.

George Friedman: Nie macie stabości Rosji i Niemiec. Polska jeszcze będzie potęga, http://wiadomosci.dziennik.pl/opinie/artykuly/460968,george-friedman-o-polityce-rosji-przyszloscipolski-i-jej-roli-w-europie.html [data dostępu: 10.03.2016].

Heywood A., Klucz do politologii, najważniejsze ideologie, systemy, postaci, Warszawa 2008.

http://data.worldbank.org/data-catalog/GDP-ranking-table [data dostępu: 10.03.2016].

http://globalfirepower.com [data dostępu: 10.03.2016].

http://obronanarodowa.pl [data dostępu: 10.03.2016].

Jackson R., Sorensen G., Wprowadzenie do stosunków międzynarodowych, Kraków 2012.

Kimla P., Historycy-politycy jako źródto realizmu politycznego, Kraków 2009.

Kimla P., U źródeł realizmu politycznego. Sofista pierwszej generacji-Protagoras z Abdery, „Politeja" 2004, nr 1.

Kwiatkowska-Drożdż A., Mocarstwo Pragmatyczne, „Nowa Europa” 2012, nr 1 (12). 
Machiavelli N., Książe, Warszawa 1993.

Malarczyk J., U źródet włoskiego realizmu politycznego: Machiavelli i Guicciardini, Lublin 1963. Morgenthau H., Politics Among Nations: the Struggle for Power and Peace, Boston 2005.

Prognoza ludności na lata 2008-2035, GUS, Warszawa 2009.

Tenerowicz R., Racjonalistyczne teorie stosunków międzynarodowych. Podobne czy różne?, [w:] Nowe spojrzenia w naukach o polityce, red. W. Jakubowski, A. Dąbrowski, M. Krzysztoszek, t. 1, Warszawa 2012.

Total Military Personnel and Dependent End Strength by Service, Regional Area, and Country, Defense Manpower Data Center, June 30, 2015.

Więcławski J., Hans Morgenthau - realizm klasyczny i jego rekomendacje dla polskiej polityki zagranicznej, „Myśl Ekonomiczna i Polityczna” 2011, nr 3 (34).

www.rodaknet.com/rp_art_5969_czytelnia_strategia_polski_george_friedman.htm [data dostępu: 10.03.2016].

www.transparency.org [data dostępu: 10.03.2016].

Zięba R., Implikacje stosunków polsko-amerykańskich dla polityki zagranicznej Polski, „Przegląd Politologiczny" 2015, nr 2.

Zięba R., Uwarunkowania polityki zagranicznej Polski na początku drugiej dekady XXI wieku, „Stosunki Międzynarodowe - International Relations" 2011, nr 1-2.

\section{SUMMARY}

The main purpose of the submitted article is to refer the realism doctrine to the contemporary Polish-Us and Polish-Russian foreign relations and to prove that the doctrine of realism is the most appropriate to provide the security for Poland. In order to bring closer the background of realism thought, in the first part, the author presents and describes its the most important precursors and their achievements beginning from antiquity. In the second part the author attempts to describe the thought of the $20^{\text {th }}$ century realists like Edward H. Carr, Hans Morgenthau and Kenneth Waltz. In the third and the last part, the rules of the realism doctrine presented above are being referred to the current security problems in Polish-Us and Polish-Russian foreign relations.

Keywords: realism; Poland; USA; Russia; Morgenthau; Carr; Waltz; security

\section{STRESZCZENIE}

Głównym celem niniejszego artykułu jest próba odniesienia założeń myśli realizmu w stosunkach międzynarodowych do współczesnych relacji polsko-amerykańskich i polsko-rosyjskich oraz wykazanie, iż to właśnie podejście realistyczne jest najwłaściwsze dla zapewnienia Polsce bezpieczeństwa. W celu przybliżenia genezy i tła myśli realistycznej autor w pierwszej części prezentuje i opisuje najważniejszych prekursorów myśli realistycznej oraz ich dokonania, zaczynając od czasów antycznych. W części drugiej podejmuje próbę opisania myśli realistów dwudziestowiecznych, takich jak Edward H. Carr, Hans Morgenthau i Kenneth Waltz. W trzeciej i zarazem ostatniej części autor odnosi wcześniej przedstawione zasady realizmu w stosunkach międzynarodowych do współczesnych problemów bezpieczeństwa w relacjach polsko-amerykańskich i polsko-rosyjskich.

Słowa kluczowe: realizm; Polska; USA; Rosja; Morgenthau; Carr; Waltz; bezpieczeństwo 